\title{
EVALUATION OF INDONESIAN ENGLISH TEXTBOOK FOR THE NINTH GRADERS OF JUNIOR HIGH SCHOOL "THINK GLOBALLY ACT LOCALLY" FROM EFL TEACHERS' PERSPECTIVES
}

\author{
Sri Handayani \\ Bambang Suwarno \\ I Wayan Dharmayana \\ English Education Postgraduate Study Program \\ Faculty of Teacher Training and Education \\ Bengkulu University, Indonesia \\ handa.srihandayani2809@gmail.com \\ wdsaraswati@gmail.com dharmayana@unib.ac.id
}

\begin{abstract}
The purpose of the study was to investigate the EFL teachers' perceptions concerning the textbook of "Think Globally Act Locally" on these criteria: (1) physical and utilitarian attributes, (2) efficient outlay of objectives and supplementary material, (3) learning- teaching content, (4) language skills and aspects. Thirty two EFL teachers of junior high school participated in this study. The instrument consisted of questionnaire and interview. Results indicated that in physical and utilitarian attributes, this textbook was perceived as

'Good', in efficient outlay and supplementary materials was perceived as 'Fair', in learning-teaching content was perceived as 'Fair', and in language skills and aspects was perceived as 'Fair'. Overall, this textbook was perceived as 'Fair'. It still needs improvement in several aspects. The illustrations should be more natural. The mistakes in this textbook should be corrected. Teaching aids like audio materials (cassette/CD), posters, and flashcards, need to accompany this textbook. The exercises should be varied. New word list and glossary should be provided to support vocabulary building and reading skill. Finally, authentic audio material like cassette/CD and phonetic transcriptions for each new word should be available for listening and pronunciation practice.
\end{abstract}

Keywords: textbook evaluation, EFL teachers' perspectives, English textbook

\section{INTRODUCTION}

There are five very important components to achieve the objectives of learning and teaching a language, they are: students, teachers, materials, teaching methods, and evaluation (Kitao, 1997). Textbooks as one of the learning materials play a very significant role in the success of teaching and learning. According to Cunningsworth (1995) textbooks provide educational text which can be used as source of material for teaching and learning. They provide objectives for the teaching process, so the teacher can choose which objective that will lead the learning process (Richards, 2001). Textbooks are a major source of providing instructions to the teachers and students, that's why it is stated that textbooks are the backbone of every educational system. They help in designing the assessment and evaluation system for the students, shaping the process of classroom teaching and learning (Mahmood, 2011). They are the core of all the educational activities because they provide students "a rich array of new and potentially interesting facts, and open the door to a 
world of fantastic experience" (Chambliss and Calfee, 1998. P. 7).

Ansary and Babaii (2002) list the argument of using textbook, they are textbook is a framework which regulates and times the programs, in the eyes of learners, no textbook means no purpose, without a textbook learners think their learning is not taken seriously, in many situations a textbook can serve as a syllabus, a textbook provides readymade teaching texts and learning tasks, a textbook is a cheap way of providing learning materials, a learner without a textbook is out of focus and teacherdependent, and perhaps most important of all, for novice teachers a textbook means security, guidance, and support.

Textbooks also provide dialogues and worksheet. So the time would not be consumed too much by the teacher to make or design some exercises for the students. In learning activity, textbook contain many materials which are used to develop students' cognitive, affective, and psychomotor skills (Littlejohn and Windeatt, 1989). To develop students' cognitive, textbooks provides lots of materials and exercises, to develop students' affective, textbooks provide dialogues. And to develop students' psychomotor skills, textbook provide some movement activities in the exercises.

Sheldon (1988) states that textbooks "represent the visible heart of any ELT program" (p.237). They consist of objectives, materials, and assessment instruments to ease the teachers for teaching and the students for learning. Even though textbook is the simple way to get instructional in teaching and learning process, teachers should be careful in selecting textbook as the source of their teaching material in the classroom. The textbook that the teachers choose would satisfy them and their students' needs. For teachers who rely much on the textbook as the main source of material, they should be careful in selecting the textbook. Since, if the textbook is not appropriate with the learners, like does not match with the learners' need and characteristics, such as age of the learners, level of the learners and also the learning style of the learners, it may mislead the students who learn English as a foreign language (EFL).

There were many previous studies which found that some textbooks were not appropriate to be used in Engish language teaching and learning. Rahayu Y.E. (2013) concluded that the English e-book entitled English in Focus for Grade IX of Junior High School was less appropriate and still needs some improvements in learning activities, methods, illustrations and pictures, and also audio-tapes. Gustin and Sundayana in Anshar et.al. (2014) in their study summarized that there were some textbooks which did not meet to the learners characteristics. Some textbooks for junior high school did not consider the level and some textbooks for senior high school did not consider the learning style of the learners. Ahour T., et al (2014) evaluated the appropriateness of "English Textbook 2" for Iranian EFL second grade high school students from the teachers' perspectives, and the results of the study indicated that generally teachers' perceptions about the criteria were not favorable. Naseem, et al. (2015) in their study concluded that English textbook for matriculation program (9th class) prescribed by Punjab Textbook Board, Lahore, Pakistan did not fulfill the general objectives of the target language.

By seeing these facts, evaluating textbook is needed to assist teacher determining the suitability of the textbook to their teaching objectives. It helps teachers knowing the weaknesses of the textbook and enables them to supplement the textbook or find other relevant and suitable teaching-learning materials based on their own specific 
needs in their own specific teaching situation.

In 2013, Indonesian Ministry of Education and Culture revised the curriculum for elementary and high schools, namely Curriculum 2013. It replaced the previous curriculum, the Curriculum 2006. This curriculum is claimed to be different from the previous one - in several aspects. One of the main differences is the implementation of scientific approach instead of communicative approach in teaching and learning.

In line with this curriculum launching, Indonesian Ministry of Education and Culture also published and distributed printed electronic books in all subjects to meet the change of the curriculum, included English textbooks, for all students and teachers in piloting schools which implement curriculum 2013 that is 6221 schools, consists of 2598 of elementary schools, 1437 of junior high schools, 1165 of senior high schools, and 1021 of vocational high schools (news.detik.com:2014). For English teaching and learning of Junior High School, the government published three series of student's English textbooks entitled When English Rings a Bell for the seventh grade students by Yuli Rulani Khatimah et al, was published in 2013 and was revised on 2014, 2016 and 2017, When English Rings a Bell for the eighth grade students by Siti Wachidah et al, was published in 2014 revised on 2016 and 2017, and 'Think Globally Act Locally' for the ninth grade students by Siti Wachidah, et al was published in 2015 and has not ever revised yet.

And at present, in 2018, the government committed that all schools in Indonesia should implement Curriculum 2013 (www.dakta.com.: 2017). It means that these textbooks are more widely used. These textbooks are prescribed by the Ministry of Education Culture of Indonesia to be taught at schools which implement the curriculum 2013 in Indonesia. Its use is a compulsory by the schools. These textbooks are designed suited the new curriculum with scientific approach and authentic assessment as the main characteristics.

Even though these textbooks were published by the government, the necessity to analyze and evaluate these textbooks was driven by the fact that these textbooks are used in large national scale. They were recently developed and their strengths and weaknesses would have a high impact on Indonesian students' English learning. Textbook evaluation is seen as an important thing to be conducted, since EFL teachers showed a dependency toward textbook in the classroom. A study conducted by Ena in Lathif (2015) showed that many Indonesian EFL teachers used textbooks as the only instructional materials in teaching-learning process. It means that they rely a lot on the textbook available. So, the quality of the textbook should be good. Therefore, teachers are required to evaluate the textbook to determine what actions they should take, whether to adopt, adapt, or supplement it.

In addition, there was also a disclaimer in this textbook which allowed everyone to give suggestion or criticism, as cited below:

"Buku ini merupakan buku
siswa yang dipersiapkan
Pemerintah dalam rangka
implementasi Kurikulum 2013.
Buku siswa ini disusun dan
ditelaah oleh berbagai pihak di
bawah koordinasi Kementerian
dan Kebudayann dan
dipergunakan dalam tahap
awal penerapan Kurikulum
2013. Buku ini merupakan
"dokumen hidup" yang
senantiasa diperbaiki,
diperbarui, dan dimutakhirkan


sesuai dengan dinamikan

kebutuhan dan perubahan zaman. Masukan dari berbagai kalangan diharapkan dapat meningkatkan kualitas buku ini".

("This is a student's book prepared by the government for the implementation of 2013 Curriculum. This student's book is organized and reviewed by various parties under the coordination of the Ministry of Education and Culture, and is used in the early stages of applying the 2013 Curriculum. This book is a "live document" which continuously improved and updated in accordance with the dynamics of the deceased and the changes of the age. Input from various circles is expected to improve the quality of this book. ")

(Wachidah, et al: 2015: ii)

Furthermore, the Minister of Education and Culture of Indonesia on his foreword in this textbook on the last paragraph also stated:

"Sebagai edisi pertama, buku ini sangat terbuka terhadap masukan dan akan terus diperbaiki untuk penyempurnaan. Oleh karena itu, kami mengundang para pembaca untuk memberikan kritik, saran dan masukan guna perbaikan dan penyempurnaan edisi berikutnya. Atas kontribusi tersebut kami mengucapkan terimakasih."

("As the first edition, the book is open for every suggestion and will continuously be improved to perfect it. Therefore, we invite readers to give suggestion and critics for improvement and perfection on the next edition. Thank you very much for the contribution."). (Wachidah, et al:2015: iv)

Based on the rationale, disclaimer and foreword citations above, it could be concluded that the government welcomed for suggestions and critics from readers, users, observers or others in order to improve the textbook in order to increase the quality of the textbook. Therefore, researcher interested to analyze and evaluate one of these textbooks, that was the third graders English student textbook entitled "Think Globally Act Locally' by Siti Wachidah, et al and was published in 2015. Other reason why researcher chose this textbook to be evaluated was because this textbook after its first publication has not been revised yet, different with the two other published textbooks for the seventh and eighth graders.

Indeed, this textbook had already reviewed by various parties under coordination of Ministry of Education and Culture, but the government will highly appreciate for everyone who gives suggestions or inputs which directed to increase this English textbook quality.

Consequently, researcher assumed that it is important to know how do the EFL teachers, as the textbook' users, perceive this student's English textbook for the ninth graders of Junior High School entitled "Think Globally Act Locally" fulfill the criteria of a good English textbook, in terms of physical and utilitarian attributes, efficient outlay of objectives and supplementary material, learning-teaching content, and language skills and aspects. Its strengths or weaknesses would have a high impact on Indonesian studentse learning of English. 
The problem of this study was formulated in the following study questions:

1. How do EFL teachers perceive the suitability of "Think Globally Act Locally" English textbook to the criteria of a good English textbook in terms of physical and utilitarian attributes?

2. How do EFL teachers perceive the suitability of "Think Globally Act Locally" English textbook to the criteria of a good English textbook in terms of efficient outlay of objectives and supplementary material?

3. How do EFL teachers perceive the suitability of "Think Globally Act Locally" English textbook to the criteria of a good English textbook in terms of learning-teaching content?

4. How do EFL teachers perceive the suitability of "Think Globally Act Locally" English textbook to the criteria of a good English textbook in terms of language skills and aspects?

To answer these questions, a descriptive study was conducted to investigate the suitability of "Think Globally Act Locally" English textbook to the criteria of a good English textbook. The objectives of this study was to investigate the teachers' perception toward the suitability of the student's English textbook for ninth grade of junior high school entitled "Think Globally Act Locally" to the criteria of a good English textbook: 1) In terms of physical and utilitarian attributes, 2) In terms of efficient outlay of objectives and supplementary material, 3) In terms of learningteaching content, 4) In terms of language skills and aspects. This study focused on evaluation from EFL teachers perspectives on the English textbook
"Think Globally Act Locally" for the ninth grade students written by Siti Wachidah, et al and was published in 2015. EFL teachers in this study refer to the secondary schools English teachers of the ninth grade in Bengkulu city, Indonesia. This study was expected to give several advantages to some parties such as EFL teachers of Junior High School, EFL teachers' association, textbook writers and publishers, Board of National Educational Standard, and other researchers in the area of English Language Education.

\section{METHODS}

This was a descriptive study. Arikunto (2010) defines descriptive study as a study which aim to investigate a certain situation, condition or other things and the result will be describe in the form of a result report. The aim of employing descriptive study is to describe the nature of a situation as it exists at the time of the study and to explore the causes of particular phenomena. This study tried to find out how do the EFL teachers' perception toward the English textbook for Junior High School for the ninth graders "Think Globally Act Locally" in terms the aspects of textbook which fulfill the criteria of good textbook in terms of physical and utilitarian attributes, efficient outlay of objectives and supplementary materials, learningteaching content, and language skills and aspects.

The present study was in-use textbook evaluation, since the student's English textbook under investigation are being used by the students in piloting junior high schools that implement Indonesian new curriculum: curriculum 2013, and the book has just been released by Indonesian Ministry of Education and Culture and have been used by the students since July 2015. All the the population was taken as the 
sample in this study that was 32 the ninth graders' EFL teachers who came from 14 junior high schools in Bengkulu city which have been implemented Curriculum 2013 and have been using English textbook which prescribed by Indonesian Ministry of Education and Culture. Two data collection methods are employed in this research: 1) questionnaire which adapted from a user- friendly 139-items fiveLikert scales of AbdelWahab (2013) textbook evaluation checklist with coefficient alpha ranged from .78 to .79 which indicated a high estimate of realibility based on the main inter-rater correlation, and 2) interview. The procedure of analyzing data are: first, specifying the phenomenon to be investigated. Second, finding out a suitable checklist of textbook evaluation. Third, distributing the questionnaire to the sample of the study. Fourth, collecting the questionnaires from the participants. Fifth, tabulating the data collected. Sixth, interviewing some of the participants. Seventh, interpreting the findings by using textbook categories: $(1,00-1,80=$ Very poor, 1 , $81-2,60=$ Poor, $2,61-3,40=$ Fair, $3,41-4,20=$ Good, 4, $21-5,00=$ Very good), and stating conclusions. Eighth, reporting the results of the study descriptively.

\section{RESULT AND DISCUSSION}

This section discusses the results of the study. The results will be presented following the order of the research questions.

The first research question was "How do EFL teachers perceive the suitability of "Think Globally Act Locally" English textbook to the criteria of a good English textbook in terms of physical and utilitarian attributes?"

In terms of the physical and utilitarian attributes aspect involves three sub-aspects: (1) general appearance, (2) layout and design, and (3) visuals of the textbook. General appearance sub-aspect considers the following 9 items: the outside cover of the textbook is informative and attractive, the font size and type used in the book are appropriate, the paper used for the textbook is of good quality, binding is strong enough, printing used is good, there is enough white space to achieve clarity, the title and sub-heading titles are written clearly and appropriately, its size is appropriate, and the textbook has sufficient number of pictures to make the situation more lifelike.

Layout and design sub-aspect, considers 12 items: there is a variety of design in a textbook to achieve impact, there is consistency in the use of headings, icons, labels, italics, etc., the textbook includes a detailed overview of the functions and structures that will be taught in each unit, the textbook has a complete and detailed table of contents, every unit and lesson is given an appropriate title, the textbook has a complete bibliography, the textbook is organized logically and effectively, an adequate vocabulary list or glossary is included, adequate review sections and exercises are included, the textbook is free of mistakes, the textbook is durable.

Visuals sub-aspect consider 4 items: the visuals should be well produced, varied and attractive, stimulate students to be creative, the visuals are functional, and the visuals are compatible with students' own culture.

The table below shows the summary of the perception of the teachers in each sub-aspect of physical and utilitarian attributes at this textbook obtained from questionnaires. It presents the findings of these sub-aspects in the form of mean of the score and its category for each. 
Sri Handayani, Bambang Suwarno, I Wayan Dharmayana

Table 1. The mean of teachers' responses to the Questionnaires in terms of Physical and Utilitarian attributes

\begin{tabular}{|l|l|c|c|}
\hline \multicolumn{2}{|l|}{ 1. Physical and Utilitarian attributes } \\
\hline Sub- aspects assessed & Mean of the score & Category \\
\hline A. & General Appearance & 4,14 & Good \\
\hline B. & Layout and Design & 3,15 & Fair \\
\hline C. & Visual & 3,27 & Fair \\
\hline & & & \\
\hline & Total Mean & $\mathbf{3 , 5 2}$ & Good \\
\hline
\end{tabular}

Table 1 reveals that the general appearance of textbook gained score 4.14 which categorized into 'Good'. Then for layout and design of the textbook was got the mean 3.15 and categorized into 'Fair'. And the last sub-aspect assessed was visual of the textbook which obtained 3.27 and also categorized into 'Fair'. In general, this aspect got total mean 3.52 which categorized into 'Good'; it means that based on the participants' perspectives, the physical and utilitarian attributes of this textbook is considered as appropriate. This finding supported by interview result in which most of the teachers perceived the physical and utilitarian of this textbook was considered as good. It means that the physical and utilitarian of this textbook fulfilled the criteria of a good English textbook. However they still suggested that this textbook still need improvement relates to its layout and design and its visuals.

In respect to layout and design which was considered as fair, teachers suggested that this textbook still need some improvement in the variety of design, overview of the function and structures, review sections and exercises, and also correcting all mistakes that are found many in this textbook, such as miss-printed, grammatical errors, the name of the characters often exchangeable, missorder of the characters in a cloze dialog or conversation, etc. This finding was in contrast with Riddell (2003) who points out that textbook should be well laidout. And there should be no mistakes in it. In line with Riddell, Byrd in CelceMurcia (2001) also says that textbook should have good presentation.

About the visuals in the textbook, which was also considered as fair, teachers suggested that it will be better if the pictures or illustrations use photographs or at least pictures which are designed more natural and more real-life like. This finding was in line with Dougill (1987) who states that the physical appearance of materials should be appealing enough to motivate learners. Moreover, Riddell (2003:100) suggests that a good textbook should be visually appealing and well laid-out. It is hoped, when the learners' interests, attention, and curiosity are attracted through attractive presentation, their motivation to the task will increase and as a result there is likely to be a better chance of learning.

A study conducted by Tok (2010) on textbook "Spot On" used in state primary school in Turkey also found that most participants actually responded unfavorably to the layout and design aspects of the book. Fitriyani (2013) conducted textbook analysis of "When English Rings the Bell" a textbook for the seventh grade of Junior High School and found that the unitizing of the textbook seems badly done. Some extent of the sub topic is not in uniting with the grand topic ones, there was even a repetition on a topic with different grand topic. Similar to this finding, a study 
conducted by Rahayu (2013) which analyzed an English e-book entitled English in Focus for Grade IX Junior High School also found unfavorable result to the visual of the textbook. All these studies confirmed the result of this study which also found that the layout and design and visual of this textbook were less appropriate, and still needs some improvement to make it better.

The second research question was "How do EFL teachers perceive the suitability of "Think Globally Act Locally" English textbook to the criteria of a good English textbook in terms of Efficient Outlay of Objectives and Supplementary Materials?"

In respect to efficient outlay of objectives and supplementary materials, there were three sub-aspects evaluated namely: (1) book objectives (2) teaching aids, and (3) teaching methods. Book objectives sub-aspect considers 10 items: the textbook fulfills the general objectives of teaching English language at the specified educational institute, the objectives are related to the learners' needs and interests, the objectives are specified explicitly in the textbook, the objectives are measurable, the objectives are relevant to the students' local culture, the objectives make a balance between the four main skills, listening, speaking, reading and writing, the objectives help the teacher to choose the right aids and the best methods of teaching, the six levels of Bloom's Taxonomy dominant in the textbook, the content underlines the importance of knowledge, and the textbook raises students' interest in further English language study.

Teaching aids sub-aspect, considers 8 items: the textbook book is supported efficiently by audio-materials, teacher's guide is available, workbook is available, cassettes are available, the pictures and diagrams required are available, the aids used help to build students' confidence, students are encouraged to bring real objects in class to illustrate some points of learning, the posters and flash cards are available and suitable.

Teaching methods sub-aspect considers 14 items: the teaching methods used in the book are the latest in the field, the methods used are student-centered, the activities allow students to talk more than teachers, the activities used allow various class activities, the activities used enable the learners to use English outside the classroom situation, the activities used enable the learners to use English outside the classroom situation, the activities can be exploited fully to acquire different language skills, activities can work well with methodologies in ELT, the textbook encourages inductive approach to learning, the textbook helps teachers exploit the activities to meet the students' expectations, activities and exercises introduce the main principles of CLT, the textbook helps teachers cater for mixed- ability students and classes of different sizes, the textbook includes lessons that reflect on study techniques, students are encouraged to take some degree of responsibility for their learning, the textbook provides opportunity for teachers and students to localize activities.

The table below presents the findings of these sub-aspects in the form of mean of the score and its category for each. 
Table 2. The mean of teachers' responses to the Questionnaires in terms of Efficient Outlay of Objectives and Supplementary Materials

\begin{tabular}{|c|c|c|c|}
\hline 2. $\mathbf{F}$ & cient Outlay of Objecti & ipplementary mate & \\
\hline & Sub- aspects assessed & Mean of the score & Category \\
\hline A. & Book Objectives & 3,48 & Good \\
\hline B. & Teaching Aids & 2,60 & Poor \\
\hline C. & Teaching Methods & 3,30 & Fair \\
\hline & Total Mean & 3,13 & Fair \\
\hline
\end{tabular}

Table 2 above reveals to the teachers' perception on the efficient outlay of objectives and supplementary materials of the textbook. In this term, there were three sub-aspects assessed. The first sub-aspect was the book objectives. This first sub-aspect gained score 3.48. It means that in general the teachers perceived the book objectives of this textbook as 'Good'. The second was teaching aids of the textbook which got score 2.60; it means that teachers perceived the teaching aids provided in this textbook as 'Poor'. And the third was teaching methods of the textbook which obtained 3.30; it means that teachers perceived the teaching methods used in this textbook as 'Fair'. In general, this aspect got total mean 3.13 which categorized into 'Fair', It means that based on the participants' perspectives, the efficient outlay of objectives and supplementary materials of the textbook was considered as moderate. This finding supported by interview result in which most of the teachers perceived the outlay of objectives and supplementary materials of this textbook as fair. It means that the objectives and supplementary materials of this textbook have not fulfilled the criteria of a good English textbook. It less appropriate to be used by the students and it still needs some improvements.

In term of teaching aids, teachers suggested that this textbook should provide audio material, like cassette or $\mathrm{CD} /$ flash disk which contain native speaker recording for listening and pronunciation-purposes activities, special workbook to enrich the students exercises, posters and flash cards, or at least web links to access those materials. This finding was not compatible with Richard (2001) who states that good textbook include a variety of learning resources and teaching aids such as workbooks, teachers' guide, CDs and cassettes, video, etc, which make the learning environment interesting and enjoyable for the learners. Similarly, Graves (2000) also states that the textbooks should include supporting materials such as teachers' guide, cassettes, worksheet and video which helps the teacher. Moreover, Suyanto (2010:101) points out that those teaching aids can help teachers extend the materials so that they will be clearer and easier to be understood by students.

Regarding to the teaching methods, teachers also suggested that this textbook still needs other methods applied which suited to the learning objectives and the students' characteristics. In line with the teachers, Masuhara (1998: 236-266) points out that a good textbook has to meet the needs of students, teachers, and administrators.

The finding on the book objectives confirmed previous studies results such as Heriati (2017) who investigated the same book with the researcher's, entitled The Analysis of Think Globally Act Locally's Book and Its Relevance to 2013 English Curriculum. The result of 
this study concluded that the materials in this textbook still applied the low level in thinking order skills of the cognitive and the psychomotor aspects. It meant that this textbook has not fulfilled one of the items in the book objectives where the textbook should dominantly covers the six levels of Bloom's Taxonomy.

Fitriyani (2013) conducted textbook Analysis of "When English Rings the Bell" for the Seventh Grade of Junior High School and concluded that from the side of age analysis, the textbook was not necessarily used on their grade although it was suitable with the curriculum nowadays, but for the real communication used, almost the students felt too easy to learn the content of this textbook. It is quite simple for their grade level. It also meant that the textbook has not fulfilled one of the criteria of good English textbook which required that an English textbook that the objectives of textbook must be related to the learners' needs and interests. While this textbook was felt too easy by the learners. It did not challenge them.Naseem, et al. (2015) evaluated English textbook for matriculation program (9th class) prescribed by Punjab Textbook Board, Lahore, Pakistan, and concluded that the textbook did not fulfill the general objectives of the target language. Tok (2010) examined English language textbook "Spot On", used in state primary schools in Turkey. The result showed that 'Spot on' was not relatively compatible with the 8th grade students' language-learning aims and actually did not raise their students' interest. All these studies showed the unfavorable result for the objectives of the book which is similar to the result of the researcher's finding. It meant that there were many studies which found that the objectives of the books under evaluated were less appropriate.

Related to teaching aids, a study conducted by Rahayu (2013) which analyzed an English e-book entitled English in Focus for Grade IX Junior High School, and a study conducted by Anshar, M.R. et.al. (2014) which evaluated English Electronic Books for Junior High school in Indonesia has similar result which concluded that the textbooks under their evaluation did not provide complete supporting aids. It was similar with the finding of the researcher's study which concluded that the teaching aids in this textbook were insufficient. Those three studies suggested that textbook should be completed with teaching aids especially cassettes or CDs of native speakers recording/videos for listening and pronunciation practices. In line with the finding of teaching methods, Alamri (2008) who evaluated the Sixth Grade English Language Textbook for Saudi Boys' Schools found that the findings were generally in favor of the textbook except for the teaching methods and some other sub-items. Moreover, Tok (2010) examined English language textbook "Spot On", used in state primary schools in Turkey, and concluded that many activities were repetitive, failed to neither encourage truly meaningful practice, promote realistic discourse, nor lead to the internalization of language. It meant that the teaching methods in the textbooks under evaluation were less appropriate to be used and should be improved.

The third research question was "To what extent does the English textbook for the seventh grade of Junior High School entitled "How do EFL teachers perceive the suitability of "Think Globally Act Locally" English textbook to the criteria of a good English textbook in terms of learning-teaching content?"

In terms of learning- teaching content, there were three sub-aspects evaluated namely: (1) subject and content (2) exercises, and (3) social and cultural context. In sub-aspect of subject 
and content considers 9 items: the material is up-to-date, it covers a variety of topics from different fields, the textbook contains fun elements, the language in the textbook is natural and real, the subject and content of the textbook is interesting, challenging and motivating, the topics encourage students to express their own views, the topics allow students to think critically, the course components are effectively and clearly organized around specific topics, the topics provide a list of new or difficult words.

While, sub-aspect of exercises considers 10 items: the exercises have clear instructions that explain how every exercise can be done, the exercises are adequate, purposeful and interesting, the exercises foster the spirit of independent learning, the textbook provides a balance of activities and tasks that focus on both fluent and accurate production, the exercises/tasks move from simple to complex, the grammar points and vocabulary items are introduced in motivating and realistic contexts, the exercises incorporate individual pair and group work, the textbook's exercises can be modified or supplemented easily, the textbook provides a variety of meaningful and mechanical exercises and activities to practice language items and skills, the textbook provides models for final achievement tests.

Social and cultural context subaspect considers 9 items: the social and cultural contexts in the textbook are comprehensible, the content of the textbook is free from stereotypical images and information, the textbook expresses positive views of ethnic origins, occupations, age groups and social groups, the content presents different cultures, the content discusses some well-known characters from different areas of the world, the content helps students be aware of how to interact using the language within a new culture that is often very different from their own, the content displays different traditions and customs, the three Ps of culture are represented in the content, the topics of the content cope with the criteria of the students' culture.

The table below presents the summary findings of these sub-aspects in the form of mean of the score and its category for each.

Table 3. The mean of teachers' responses to the Questionnaires in terms of Learningteaching content

\begin{tabular}{|l|l|c|c|}
\hline \multicolumn{3}{|c|}{ 3. Learning-teaching content } \\
\hline Sub- aspects assessed & Mean of the score & Category \\
\hline A. & Subject and Content & 2,94 & Fair \\
\hline B. & Exercises & 3,01 & Fair \\
\hline C. & Social and cultural context & 3,18 & Fair \\
\hline & & & Fair \\
\hline & Total Mean & $\mathbf{3 , 0 4}$ & .
\end{tabular}

Table 3 reveals that in term of the learning-teaching content of the textbook, there were three sub-aspects evaluated. The first sub-aspect was the subject and content of the textbook. This sub-aspect gained score 2.94; it means that teachers perceived the subject and content in this textbook as 'Fair'. The second was the exercise of the textbook which got score 3.01; it means that teachers perceived the exercises in this textbook as 'Fair'. And the third was social and cultural of the textbook which obtained 3.18; it means that teachers also perceived the social and cultural contexts in this textbook as 'Fair'. In 
general, this aspect got total mean 3.04 which categorized into 'Fair', It means that based on the participants' perspectives, the efficient outlay of objectives and supplementary materials of the textbook was considered to be fair. This finding was similar with the interview result, that was mostly interviewrs perceived that the subject and content of this textbook was considered as fair. It means that this the subject and content of this textbook have not fulfilled the criteria of a good English textbook, and need improvement in some aspects.

Relating to the subject and content, teachers suggested that some long and difficult texts should be simplified. This textbook should provide new wordlist and glossary to ease the students to comprehend the texts, and it will be better if the grammar materials are added both the explanation and the exercises. For narrative, procedure and report texts with their exercises should be added and varied as well. Riddell (2003:100) states that a good textbook should contain thought provoking issue to challenge to students. The subject and content of the textbook should be interesting, challenging and motivating. In addition, Byrd (in Celce-Murcia: 2001:416) suggests that textbook should contain meaningful and interesting content.

In addition, in terms of the exercises, teachers also suggested that this textbook should also provides various exercises such as completing, short answer questions, matching, truefalse, synonym-antonym, arranging jumbled words/sentences, and the most important was multiple choices since this will be helpful for the ninth graders to prepare them facing many exams, especially national examination which use multiple choice questions. This finding was in contrast with Riddell (2003:100) who suggests that textbook should have varied and balanced language works, skill work, pronunciation, etc. Similarly, Byrd (cited in Celce-Murcia, 2001:416) states that good textbook should also contain doable and varied tasks, beside meaningful content, usable examples, and presentation of textbook.

Moreover, concerning to socialcultural contexts of the textbook, teachers suggested that it will be better if this textbook also provide social and cultural context of English speaking countries, with ratio $30 \%-40 \%$ for English speaking countries context, and $60 \%-70 \%$ for Indonesian context. It aims to increase the students' knowledge of English speaking countries culture in order to avoid miss understanding or culture shock if they have a chance to communicate with English native speakers or to go to English speaking countries. This finding was in contrast with Liddicoat, et al. (cited in Scarino and Liddicoat: 2009) who points out that in language learning classrooms, learners need to engage with the ways in which context affects what is communicated and how. Both the learner's culture and the culture in which meaning is created or communicated have an influence on the ways in which possible meanings are understood. This context is not a single culture as both the target language and culture and the learner's own language and culture are simultaneously present and can be simultaneously engaged. When language is learnt, the social and cultural context in which it is used needs to be taken into consideration. Therefore, target culture should be included in this EFL textbook even though in a small portion. Teaching of a language cannot be separated that of its culture. So, if they only use this textbook, they will miss it since there are no social and cultural culture of English speaking countries at all in it. To overcome it, teachers should introduce English culture while at the 
same time teach the language to their students although it is not available in this textbook. Later, hopefully the textbook writer will include the culture of English speaking countries in revising this textbook.

Samples studies that reflect the lacking of subject and content was conducted by Ahour T., et.al. (2014) which evaluated the appropriateness of "English Textbook 2" for Iranian EFL second grade high school students from the teachers' perspectives. The results of the study revealed that based on the teachers' viewpoints, the subject and content of the textbook was not relevant to the students' interest, needs, and concerns. There was not also sufficient variety in the subject and content of the textbook. Wijayanti (2016) on her study 'Lived Experience in Using the 2013 Curriculum-Based Textbook: Think Globally Act Locally' found that the teachers understood that the 2013 curriculum-textbook for grade 9 was not compatible with the national examination's materials, therefore they took their own measures to adapt, modify, and if necessary alter the content or the exercises in the textbook. Heriati (2017) investigated the same book with the researcher's, entitled The Analysis of Think Globally Act Locally's Book and Its Relevance to 2013 English Curriculum. The result of this study showed that the materials in this textbook materials are enough relevant with 2013 curriculum, but the materials are still applied the low level in Thinking Order Skills of the cognitive and the psychomotor aspects. Unfavorable findings on exercises and activities on the textbook was conducted by Ahour T., et al (2014) which evaluated the appropriateness of "English Textbook 2" for Iranian EFL second grade high school students from the teachers' perspectives. The results of the study revealed that the exercises and activities in the textbook do not involve and encourage sufficient communicative and meaningful practice. Anshar, M.R. et.al. (2014) also evaluated English Electronic Books for Junior High school in Indonesia. Both textbooks need some improvement on how to design the activities.

The fourth research question was "How do EFL teachers perceive the suitability of "Think Globally Act Locally" English textbook to the criteria of a good English textbook in terms of language skills and aspects?"

In the domain of language skills, there were four sub-aspects evaluated namely: (a) listening (b) speaking (c) reading, and (d) writing. Listening skills considers 7 items: the textbook has appropriate listening tasks with welldefined goals, the listening passages help students develop their listening comprehension skills, the cassettes expose the students to the voices and pronunciation of the native speakers of English, listening material is well recorded, as authentic as possible, tasks are efficiently graded according to complexity from literary, inferential to critical listening skills, listening material is accompanied by background information, questions and activities, the listening exercises focus on linguistic competence such as stress, intonation and form.

The speaking skills considers 6 items: activities are developed to encourage student-student and studentteacher oral communication, activities are balanced between individual response, pair work and group work, activities help students become a more confident English speaker, speech exercises invite students to talk about their concerns and interests, the situations in the dialogues sound natural, there is sufficient material for spoken English (e.g. dialogues, role-plays, etc.) that help to de-emphasize teacher's talk.

Reading skill sub-aspect considers 6 items: there is sufficient reading 
material (there is a range of varied and interesting reading text that can engage students cognitively and effectively), the content helps students develop reading comprehension skills, many of the reading passages are up-to-date, interesting and meaningful, some reading passages are easy for most of the students to deal with, the length of the reading texts is appropriate, the textbook uses authentic (real world) reading material at an appropriate level.

Writing skill sub-aspect considers 8 items: tasks have achievable goals and take into consideration learners' capabilities, writing tasks are interesting, the writing tasks enhances free writing opportunities, the time allotted for teaching the material is sufficient, some writings are easy for most of the students to deal with, writings in the textbook are guided and controlled, the textbook leads students from simple controlled writing activities to guided writing activities, writing activities are suitable in terms of length, degree of accuracy, and amount of guidance.

The table below presents the findings of these sub-aspects in the form of mean of the score and its category for each.

Table 4. The mean of teachers' responses to the Questionnaires in terms of Language Skills

\begin{tabular}{|l|l|c|c|}
\hline \multicolumn{4}{|l|}{ 1) Language Skills } \\
\hline \multicolumn{2}{|c|}{ Sub- aspects assessed } & Mean of the score & Category \\
\hline (a) & Listening & 1,70 & Very Poor \\
\hline (b) & Speaking & 3,28 & Fair \\
\hline (c) & Reading & 3,05 & Fair \\
\hline (d) & Writing & 2,96 & Fair \\
\hline & & & \\
\hline & Total Mean & $\mathbf{2 , 7 5}$ & Fair \\
\hline
\end{tabular}

Based on the table 4 above, the language skills in the textbook were divided into four sub-aspects which were evaluated. The first sub-aspect was listening. This sub-aspect gained score 1.70 ; it means that teachers perceived the worthiness of listening skill in this textbook as 'Very Poor'. The second was speaking which got score 3.28; it means that teachers perceived the worthiness of speaking skill in this textbook as 'Fair'. The third was Reading which obtained 3.05; it means that teachers perceived the worthiness of reading skills in this textbook as 'Fair'. And the fourth was Writing which got score 2.96; which means that teachers perceived the worthiness of writing skills materials in this textbook also as "Fair". In general, this aspect got total mean 2.75 which categorized into 'Fair',
It means that based on the participants' perspectives, the language skills in this textbook was considered to be fair. This finding was in line with the interview result, in which most interviewers perceived that the language skills of this book was considered as fair. It means that the language skills of this textbook have not fulfilled the criteria of a good English textbook. Improvement in some aspects are needed to make this textbook appropriate to be used by the students.

Teachers suggested that for listening skills, specific listening sections accompanied by cassette or CD should be provided in this textbook. Cassette /CD/flash disk contained recording of English native speakers which made for listening materials purpose will make the students more exposed and familiarized with the 
intonation and pronunciation from native speakers, and hopefully it will have better impact for students' listening skills. This finding was in contrast with Grant (1991) who says that a textbook should be accompanied by cassettes for listening as cassettes provide models for students to imitate the pronunciation of the sounds, words, phrases or sentences. As listening activities provide authentic input to the students, the number and the form of listening activities should be taken into account. The activities must be designed in interesting and meaningful ways following the nature of listening in real life communication.

Regarding to speaking skills, teachers suggested that the exercises for speaking skill should be varied, especially exercises which designed for speaking self-production by the students. Cunningsworth (1995) points out that in textbooks, speaking is presented in oral presentation, language practice, oral work, and role play. These activities should give a balance between the acquisition of new language skills and the amount of practice. Also, some principles of pronunciation practice should also be integrated in order to facilitate the learners to produce accurate spoken utterances.

Relating to reading skill, teachers perceived as good. This finding was compatible with Ur (1996:188) who states that realizing the importance of reading texts as an input for the students, the texts and activities presented in a textbook should cater their interest. Similarly, Cunningsworth (1995:75) points out some dimensions of reading materials which should be taken into consideration in presenting reading materials. The first issue is related to the topic (interests, levels of challenge, cultural acceptability, and so on). The second issue deals with different type of genre which is related to the range of students' ability. In this issue, this textbook fulfilled sufficiently the students' interests and level of challenge, and also its cultural acceptability since this textbook mostly presented Indonesian culture. So, the students could accept the cultural contexts easily. The third issue is related to the exercise and activities which students engaged in. In this term, this textbook was considered as fair, since the exercises for reading skill in this textbook were less varied. So, teachers suggested that to make it better, in every reading text should be followed by varied exercises like short answer question, matching, synonym and antonym, multiple choices, etc. Multiple choice questions is very important for students to prepare them facing examination which mostly using this kind of question. And, this book should provide new word list after each text and glossary in the last part of this textbook to ease the students comprehend the texts.

Moreover, in respect to writing skill, teachers suggested that the exercises for writing should be varied. For example, the textbook provide series of pictures or some clues to guide students to write procedure, narrative, descriptive, and report text. Those clues and pictures will ease the students to produce their own texts. The textbook also should provide example first to make the students write by themselves. In line with this, Ferris and Hedgecock (2005:129) states that in general, writing activities in textbooks acquire the students to produce something based on the model given. The emphasis of this will be on the teaching writing skills, strategies, and processes in a sequential way. This is realized through many types of activities presenting on textbooks. These consist of controlled, guided, and free writing activities such as filling gaps, dictation, filling in forms, and free writing. Cunningsworth (1995:81) states that textbook should also present how words are combined 
into a meaningful discourse structure. This also means looking beyond the mechanics of writing at the sentence level. By so doing, students will develop their literacy skills allowing them use different texts appropriately.

This finding confirmed a previous study result from Ahour T., et al (2014) conducted a study which evaluated the appropriateness of "English Textbook 2" for Iranian EFL second grade high school students from the teachers' perspectives. The results of the study showed that the textbook does not pay attention to the listening, speaking, and writing skill and only the reading skill is emphasized. In respect to language aspects, there were three sub-aspects evaluated namely: (a) vocabulary (b) grammar, and (c) pronunciation. Vocabulary sub-aspect considers 11 items: the load (number of new words in each lesson) is appropriate to the linguistic level of students, there is a good distribution (simple to complex) of vocabulary load across the whole book, the exercises for vocabulary are rich and adequate, words are contextualized, the topical nature of the vocabulary exercises is often meaningful to the students, new lexical items appear in each unit, there is specific method to teach new vocabulary, the sentences and examples use words that are known by learners, there is a list of vocabulary items tagged at the end of the textbook, the content involves culture-specific items, words are accompanied with their phonetic transcription in English.

Grammar sub-aspect considers 11 items: the grammar is contextualized, the grammar examples are interesting and appropriate to the students' level, grammar is introduced explicitly, the exercises for grammar practice are rich and adequate, structures are designed to be taught inductively, grammar lessons are often derived from the listening or reading passages, the time allotted for teaching the material is sufficient, grammatical structures of statements are easy to be understood, there is a balance between form and use, the textbook covers the main grammar items appropriate to students at this grade, the grammar points are presented with brief and easy examples and explanations.

Pronunciation sub-aspect considers 5 items: pronunciation is easy to be learnt, pronunciation is built through other types of activities, such as listening, dialogue, etc., there are cassettes/CDs for pronunciation practice, the textbook highlights and practices natural pronunciation (that is, stress and intonation), the textbook includes adequate material for pronunciation work. The table below presents the findings of these subaspects in the form of mean of the score and its category for each.

Table 5. The mean of teachers' responses to the Questionnaires in terms of Language Aspects

\begin{tabular}{|l|l|c|c|}
\hline \multicolumn{4}{|l|}{ 2) Language Aspects } \\
\hline Sub- aspects assessed & Mean of the score & Category \\
\hline (a) & Vocabulary & 2,41 & Poor \\
\hline (b) & Grammar & 3,01 & Fair \\
\hline (c) & Pronunciation & 1,84 & Poor \\
\hline & & & \\
\hline & Total Mean & $\mathbf{2 , 5 8}$ & Poor \\
\hline
\end{tabular}

Table 5 shows that in terms of the language aspects in this textbook, there

were three sub-aspects evaluated. The first sub-aspect was vocabulary. This 
sub-aspect gained score 2.41; it means that teachers perceived the materials for vocabulary in this textbook as 'Poor'. The second was the grammar which got score 3.0 ; it means that teachers perceived the materials for grammar in this textbook as 'Fair'. And the third was pronunciation which obtained 1.84; it means that teachers perceived the materials for pronunciation in this textbook as 'Poor'. In general, this aspect got total mean 2.58 which categorized into 'Poor'. It means that based on the participants' perspectives, the language aspects in the textbook was considered to be lacking. This finding was supported by interviewers opinion who said that the language aspects of this book as fair. It means that the language aspects of this textbook have not fulfilled the criteria of a good English textbook. So, it still need many improvement in some aspect to make this textbook worthy.

In respect to vocabulary, teachers suggested that it will be better if this book provide some specific exercises for vocabulary, and provide new word list after each text and glossary at the end part of the textbook. It will help and ease the students to comprehend the text. Komachali \& Khodareza (2012) who states that textbooks which provide word list and accompanied by flashcard are preferred. Since, utilizing flashcard and wordlist in teaching vocabulary considered helpful. Moreover, Baleghizadeh \& Ashoori (2011) define word list as a sheet paper where learners write the second language (L2) along with their first language (L1) definition). In addition Thornbury (2002) states that word list is one of effective strategy that can be applied classroom because it is cheap and widely-used among the students. It can also be learned in short time. Regarding to this strategy, Sitompul (2013) investigated the teaching vocabulary using flashcards and word list as strategies in the experimental and control group. The results showed that students' vocabulary mastery improved after they were taught by using flashcards and wordlist.

In respect to grammar finding, teachers suggested that this textbook should also provide grammar explanation more explicitly, and add specific grammar exercises, although a few. This finding was in contrast with Ellis (2006) who discusses two approaches relating to grammar teaching: deductive and inductive. Grammar instruction should take the form of separate grammar lessons (a focus-on-forms approach) and should also be integrated into communicative activities (a focus on-form approach). Mohammed \& Jaber, (2008) also state that deductive and inductive are the most common approaches used to conceptualize and apply grammar in ELT materials. Ming-jun (2008) points out that the deductive approach introduces grammatical rules first and then they are applied by students. On the other hand, the inductive approach presents new grammatical structures to students in a real language context, so that the students learn the rules from the context.

And concerning to pronunciation, teachers suggested that this textbook should provide phonetics transcription for each new word on the word lists and glossary. Cassette/CD/flash disk which contain recording of English native speaker which designed for both listening and pronunciation practices should accompany this textbook. Unfortunately, either phonetics transcription, cassette/CD/flash disk which contain recording of native speakers were not available in this textbook. This was not in line with Grant (1991) who says that a textbook should be accompanied by cassettes for listening as cassettes provide models for students to imitate the pronunciation of the sounds, words, phrases or 
sentences. Audio-tapes/cassettes/CDs which include English native speakers conversations, dialogs, songs, etc are really helpful for the students to give them authentic model in pronouncing English words correctly.

A study which has favorable result on language aspects was conducted by Prihatianti (2011) entitled Content Analysis Of English Textbook Used By First Grader Of Senior High School Level "Look Ahead" Published By Erlangga. The results showed that the textbook was considered relevant to the EFL textbook evaluation criterion, and fulfilled the criteria of good textbook in terms of objectives, vocabulary, good grammar presentation and practice, educationally and socially acceptable, explanation and practice, periodic review and test sections, appropriate visual materials, interesting topic and test, clear instructions, clear attractive layout, content clearly organized and graded, fluency practice in all four skills, encourage learners. In contrast, Cakit (2006) conducted an evaluation of the EFL Textbook "New Bridge to Success 3" from the Perspectives of Students and Teachers. The results found that the reading passages needed to be simplified in terms of both vocabulary load and structures. This result is similar with one of the researcher's result in this study which revealed that some of the reading texts in this textbook should be simplified since they were felt difficult by some students in many schools, moreover the school which located in the remote areas in Indonesia.

Moreover, the summary of the textbook evaluation using questionnaires will be displayed in the following table.

Table 6. Summary of the textbook evaluation through questionnaires.

\begin{tabular}{|c|l|c|c|}
\hline \multicolumn{2}{|c|}{ Aspects assessed } & Total Mean & Category \\
\hline 1. & Physical and Utilitarian attributes & 3,52 & Good \\
\hline 2. & $\begin{array}{l}\text { Efficient Outlay of Objectives and } \\
\text { Supplementary materials }\end{array}$ & 3,13 & Fair \\
\hline 3. & Learning-teaching content & 3,04 & Fair \\
\hline 4. & Language Skills and Aspects & 2,67 & Fair \\
\hline & A. Language Skills & $(2,75)$ & (Fair) \\
\hline & B. Language Aspects & $(2,58)$ & (Poor) \\
\hline & & & \\
\hline & & $\mathbf{3 , 0 0 4}$ & Fair \\
\hline
\end{tabular}

Table 6 reveals that there were 4 main aspects assessed in the textbook evaluation of this research. The teachers perceived the first aspect which was physical and utilitarian attributes as good $(\mathrm{M}=3.52)$, then the teachers perceived the second aspect which was efficient outlay of objectives and supplementary materials as fair $(\mathrm{M}=3.13)$. Moreover, the teachers perceived the third aspect which was learning-teaching content as fair $(\mathrm{M}=3.04)$ and the fourth aspects which were language skills and aspects as fair
$(\mathrm{M}=2.67) ;$ in detail, the teachers perceived the language skill as fair $(\mathrm{M}=2.75)$ and the language aspect as poor $(\mathrm{M}=2.58)$. Thus, the teachers perceived all of the aspects of the textbook as fair $(M=3.00)$.

These summaries were in line with the interview result. In general, the interviewees perceived that physical and utilitarian attributes as good; the efficient outlay of objectives and supplementary materials as fair; the learning-teaching content as fair; and the language skills and aspects as fair; in 
detail, the teachers perceived the language skill as fair and the language aspect as poor.

Overall, the teachers perceived all of the aspects of the textbook as fair. It means that this textbook was less appropriate to be used by the students and needs improvement in several aspects to make it appropriate.

\section{CONCLUSION AND SUGGESTION}

\section{Conclusion}

Based on the result of the study through questionnaires and interview, it can be concluded that the perceptions of the ninth graders' EFL teachers of Junior High School in Bengkulu City which have been implement 2013 Curriculum to the English textbook for grade 9 of Junior High School entitled 'Think Globally Act Locally", were as follow:

1. In terms of physical and utilitarian attributes, teachers perceived this textbook as 'Good'.

2. In terms of efficient outlay and supplementary materials, teachers perceived this textbook as 'Fair'

3. In terms of learning-teaching content, teachers perceived this textbook as 'Fair'

4. In terms of Language Skills and Aspects, teachers perceived this textbook as 'Fair', with the below details:
a. In terms of language skills, teachers perceived this textbook as 'Fair'.
b. In terms of language aspects, teachers perceived this textbook as 'Poor'

In general, teachers perceived this textbook as 'Fair'. It means that this textbook was less appropriate to be used by the students. It still needs some improvement in many aspects.

\section{Suggestion}

Based on the results of this study, there are some suggestions which are expected to be advantageous for any parties, as follow:

1. For EFL teachers of Junior High School

EFL teachers of Junior High School who are using textbook "Think Globally Act Locally" has to find ways to overcome its weaknesses by doing some adjustments. They should provide additional explanation for grammar, provide many more variation of exercises in listening, speaking, reading, and writing (such as short answer question, matching, true-false, arranging jumbled words/sentences, and multiple choice, etc.), provide new wordlists, check and correct the mistakes in the textbook before learning process take place, prepare and bring suitable teaching aids like pictures, poster, realia, and also cassettes/CD/video (for listening and pronunciation practices) to the classroom.

2. EFL teachers' Association of Junior High School

The EFL teachers' Association of Junior High School can generate the EFL teachers to work collaboratively to do evaluation to other textbook, or to make additional materials to supplement "Think Globally Act Locally" textbook.

3. For English Textbook Writer and Publisher

Textbook writer and publisher should realize that many EFL teachers in Indonesia still textbook-dependent. They rely much on textbook on their teaching 
process. Also, it should be noted that not all them understand how to adapt, modify some aspects containing weaknesses on textbook, and find other materials to supplement it. Therefore, complete and good quality textbook is needed.

Based on the findings of this study, the visuals of this book still need improvement. They should be made more natural or real-life like. The exercises should be more varied such as completing, short answer question, matching, true-false, arranging jumbled words/sentences, multiple choice, etc. in listening, speaking, reading, and writing skills. New/unfamiliar wordlists and glossary should be provided in this textbook. Eliminating the mistakes in the textbook is a must since it may lead the students' and teachers' confusion in doing the exercises and distrust to the textbook which will affect to the success of the students' learning. Providing teaching aids like pictures, poster, flashcards, and also cassettes/CD/video (for listening and pronunciation practices) is also required to accompany the textbook. 4. For further studies in English
Language Study Program

This study can be used as a reference for future researchers in textbook evaluation area, or other related study in the area of material development. They can do researches in developing textbook based on the criteria of good textbook applied in this study and considering some corrections and suggestions given to the results of this study by the EFL teachers.

\section{For Board of National Educational Standard}

The findings of this study can be used as additional information to make some revision in some aspects to the textbook under evaluation "Think Globally Act Locally".

\section{REFERENCES}

AbdelWahab, M.M. (2013). Developing an English language textbook evaluative checklist. IOSR Journal of Research \& Method in Education (IOSR-JRME) e-ISSN: 2320-7388, p-ISSN: 2320-737X Volume 1, Issue 3 (Mar. -Apr. 2013), PP 5570. Retrieved from www.iosrjournals.org.

Ahour, T., Towhidiyan B., \& Saeidi M., (2014). The evaluation of "English textbook 2" in Iranian high schools from teachers' perspectives. English language teaching; Vol. 7, No. 3; 2014. ISSN 1916-4742 EISSN 1916-4750. Published by Canadian Center of Science and Education. Retrieved from http://www.ccsenet.org/journal/inde x.php/elt/article/viewFile/34248/19 $\underline{570}$

Alamri, A. A. M. (2008). An evaluation of the sixth grade english language textbook for Saudi's boys' schools. Kingdom of Saudi Arabia. Ministry of Higher Education. King Saud University. Deanship of Higher Studies. Department of English Language. Retrieved from http://faculty.ksu.edu.sa/amri/Docu ments/MA\%20thesis.pdf

Ansary and Babaii. (2002). Universal characteristics of EFL/ESL textbooks: a step towards systematic textbook evaluation. Retrieved on February 26, 2018 from http://iteslj.org/Articles/AnsaryTextbooks/.

Anshar, M.R., Emilia E., \& Damayanti, I.L. (2014). The evaluation of 
English electronic books for junior high school in Indonesia. In Edusentris. Jurnal Ilmu Pendidikan dan Pengajaran Vol.1 No.3 Desember 2014. University of Education. Bandung. Retrieved from http://repository.upi.edu/6770/

Arikunto, S. (2012). Prosedur penelitian: Suatu pendekatan praktik. Jakarta, Indonesia: Rineka Cipta.

Baleghizadeh \& Ashoori, A. (2010). The effect of keyword and word list methods on immediate vocabulary retention of EFL learners. Pakistan Journal of Social Sciences, 35 (2): 251-261

Cakit, I.. (2006) Evaluation of the EFL textbook "New Bridge to Success 3 " from the perspectives of students and teachers. Thesis. School of Social Sciences of The Middle East Technical University.

Celce-Murcia, (2001).Teaching English as a second or foreign language (3rd Edition). Retrieved from .http://www.tesl-

ej.org/wordpress/issues/volume5/ej 20/ej20r4/.

Chambliss, M., \& Calfee, R. (1998). Textbooks for learning: Nurturing children's minds. Oxford, England: Blackwell Publishers.

Cunningsworth, A. (1995). Choosing your coursebook. London, England: Macmillan: Heinemann.

detikNews. (2014). Mendikbud: Ada 6221 sekolah yang akan menjadi percontohan kurikulum 2013. Retrieved from http://news.detik.com/berita/27693 31/mendikbud-ada-6221-sekolah- yang-akan-menjadi-percontohankurikulum-2013

Dougill, J. (1987). Not so obvious. In L.E. Sheldon (ed). ELT Textbook and Materials: Problems in evaluation and development, (pp. 29-35). Oxford, England: Modern English Publication.

Ellis, R. (2006). Current issues in the teaching of grammar: an SLA perspective. TESOL Quarterly, vol. 40, no. 1, pp. 83-107. Retrieved from

https://languesulb.wikispaces.com/f ile/view/ellis_grammar-1.pdf.

Ferris D.R. \& Hedgecock, J.S. (2005). Teaching ESL composition: Purpose, process, and practice. Mahwah, NJ: Lawrence Elbaum Associates.

Fitriyani, M. (2013). A textbook analysis of when english rings the bell, a textbook for seventh grade of Junior High School. Faculty of Languages and Arts of the State University of Yogyakarta, Indonesia.

Grant, C. (1992). Best practices in teacher preparation for urban schools. Paper prepared for the 1992 AERA Symposium, San Francisco, USA.

Graves, K. (2000). Designing language courses: A guide for teachers. Boston, MA: Heinle and Heinle Publishers.

Heriati, R. (2017). The analysis of think globally act locally's book and its relevance to 2013 English curriculum. Undergraduate thesis, IAIN Palangka Raya, Indonesia. Retrieved from http://digilib.iainpalangkaraya.ac.id/827/. 
Khodareza \& Komachali, E. (2012). The effect of using vocabulary flashcard on Iranian on Iranian pre-university students' vocabulary knowledge. Canadian Center of Science and Education Journal, 5 (3): 134-147.

Kitao, K., Kitao, S.K. (1997). Selecting and developing teaching/learning materials. The Internet TESI journal, IV (4), April 1997. Retrieved from http://iteslj.org/Articles/KitaoMaterials.html

Littlejohn A. and Windeatt. (1989). Beyond language learning: Perspective on materials design. In RK Johnson (ed) The second language curriculum. Cambridge, England: Cambridge University Press.

Mahmood, K. (2011). Conformity to quality characteristics of textbooks: the illusion of textbook evaluation in Pakistan. Journal of Study and Reflections in Education, Vol.5, No.2, pp 170 -190. Retrieved from http://ue.edu.pk/jrre/articles/52006. pdf.

Masuhara, H.(1998). What do teachers really want from textbook? In Tomlison, B. Materials Development for Language Teaching. Cambridge, England: Cambridge University Press.

Ming-jun. (2008). Principal approaches of grammar instruction. Retrieved from

https://www.studygate.net/publicati on/238570266_Principal_approach es_of_grammar_instruction.

Mohammed \& Jaber. (2008). The effects of deductive and inductive approaches of teaching on
Jordanian University students' use of the active and passive voice in English. Retrieved from https://eric.ed.gov/?id=EJ816940.

Suyanto, K.E. (2010). English for young learners. Jakarta, Indonesia: Sinar Grafika Offset.

Thornbury, S. (2002). How to teach vocabulary. Harlow, England: Longman, Pearson Education Limited.

Tok, H. (2010). TEFL textbook evaluation: From teachers ${ }^{\text {ee }}$ perspectives. Educational Study and Review Vol. 5 (9), pp. 508-517, September 2010. ISSN 1990-3839 (C) 2010 Academic Journals. Retrieved from http://www.academicjournals.org/jo urnal/ERR/article-fulltextpdf/3CAEBA44186

Ur, P. (1996). A course in language teaching : Practice and theory. Cambridge, England : Cambridge University Press.

Wachidah, et al. (2015). Think Globally Act Locally Grade IX. Kementerian Pendidikan dan Kebudayaan. Jakarta, Indonesia.

Wijayanti. (2016). Lived experience in using the 2013 curriculum-based textbook: Think Globally Act Locally. Universitas Sanata Dharma. Yogyakarta, Indonesia.

www.dakta.com. (2017). Tahun 2018 seluruh sekolah diharapkan terapkan kurikulum 2013. Retrieved from http://www.dakta.com/news/12915/ tahun-2018-seluruh-sekolahdiharapkan-terapkan-kurikulum$\underline{2013}$ 